\title{
Correction to: Levels and risks of surface contamination by thirteen antineoplastic drugs in the Czech and Slovak hospitals and pharmacies
}

\author{
Lenka Doležalová ${ }^{1,2} \cdot$ Lucie Bláhová $^{3} \cdot$ Jan Kuta ${ }^{3} \cdot$ Tereza Hojdarová $^{3} \cdot$ Šárka Kozáková $^{4} \cdot$ Luděk Bláha $^{3}$
}

Published online: 3 March 2022

๑) Springer-Verlag GmbH Germany, part of Springer Nature 2022

\section{Correction to: Environmental Science and Pollution Research} https://doi.org/10.1007/s11356-021-17607-y

The $1^{\text {st }}$ Author has 2 affiliations and it is modified in the original published proof.

The Original article has been corrected.

Publisher's note Springer Nature remains neutral with regard to jurisdictional claims in published maps and institutional affiliations.

The original article can be found online at https://doi.org/10.1007/ s11356-021-17607-y.

Luděk Bláha

ludek.blaha@ recetox.muni.cz

1 Masaryk Memorial Cancer Institute, Žlutý kopec 7, 65653 Brno, Czech Republic

2 Faculty of Pharmacy, Masaryk University, Palackeho 1946/1, 61200 Brno, Czech Republic

3 Faculty of Science, Masaryk University, RECETOX, Kamenice 753/5, Building D29, 62500 Brno, Czech Republic

4 University Hospital Brno, Jihlavská 20, 62500 Brno, Czech Republic 